\title{
Molecular characterization of the pathogenic plant fungus Rhizoctonia solani (Ceratobasidiaceae) isolated from Egypt based on protein and PCR-RAPD profiles
}

\author{
M.A. Mahmoud ${ }^{1}$, S.A. Al-Sohaibani ${ }^{1}$, A.M.M. Abdelbacki ${ }^{2}$, M.R.Al-Othman ${ }^{1}$, \\ A.R.M. Abd El-Aziz', K.K. Kasem³ , M.S. Mikhail' ${ }^{2}$ K.K. Sabet ${ }^{2}$, M.R. Omar ${ }^{4}$ \\ and E.M. Hussein ${ }^{4}$ \\ ${ }^{1}$ Botany and Microbiology Department, College of Science, \\ King Saud University, Riyadh, Saudi Arabia \\ ${ }^{2}$ Plant Pathology Department, Faculty of Agriculture, \\ Cairo University, Giza, Egypt \\ ${ }^{3}$ Agriculture Research Centre, \\ General Commission for Scientific Agriculture Research, Hamah, Syria \\ ${ }^{4}$ Plant Pathology Research Institute, Agriculture Research Centre, Giza, Egypt \\ Corresponding author: M.A. Mahmoud \\ E-mail: momahmoud@ksu.edu.sa
}

Genet. Mol. Res. 11 (4): 3585-3600 (2012)

Received November 29, 2011

Accepted June 4, 2012

Published October 4, 2012

DOI http://dx.doi.org/10.4238/2012.October.4.6

\begin{abstract}
Twenty-one isolates of Rhizoctonia solani were categorized into three anastomosis groups consisting of AG-4-HG-I (eight isolates), AG-2-2 (nine isolates) and AG-5 (four isolates). Their pathogenic capacities were tested on cotton cultivar Giza 86. Pre-emergence damping-off varied in response to the different isolates; however, the differences were not significant. Soluble proteins of the fungal isolates were electrophoresed using SDS-PAGE and gel electrophoreses. A dendrogram of the protein banding patterns by the UPGMA of arithmetic means placed the fungal isolates into distinct groups. There was no evidence of a relationship between protein dendrogram, anastomosis grouping or level of virulence or geographic origin. The dendrogram generated from these isolates based on
\end{abstract}


PCR analysis with five RAPD-PCR primers showed high levels of genetic similarity among the isolates from the same geographical locations. There was partially relationship between the genetic similarity and AGs or level of virulence or geographic origin based on RAPD dendrogram. These results demonstrate that RAPD technique is a useful tool in determining the genetic characterization among isolates of $R$. solani.

Key words: Rhizoctonia solani; Cotton; Anastomosis groups; Pathogenicity; SDS-PAGE; RAPD-PCR

\section{INTRODUCTION}

Rhizoctonia solani Kühn, the anamorphic of Thanatephorus cucumeris (Frank) Donk, causes seedling blight, pre- or post-emergence damping-off, sore shin and root rot of cotton seedlings (Fulton et al., 1956). The $R$. solani complex represents an economically important group of soil-borne pathogens that occur on many plant species throughout the world (Sneh et al., 1996). $R$. solani is composed of genetically isolated groups (Adams, 1988). The identification and classification of these groups is primarily based on anastomosis behavior (Ogoshi, 1972). R. solani is a heterogeneous species that has been divided into 14 anastomosis groups (AGs), designated as AG-1-13 and a bridging isolate group, AG-BI (Carling et al., 2002; El-Samawaty, 2008). Some isolates of $R$. solani AG-2-2, AG-4 and AG-5 reduce emergence of maize, cotton and sorghum seedlings (Rush et al., 1994).

The pathogenicity of 39 isolates of $R$. solani AG-4 and one isolate of AG-2-2 were evaluated on the cotton cultivar Giza 75 under greenhouse conditions; most of the virulent isolates exhibited pre-emergence damping-off (El-Akkad, 1997). Gel electrophoresis of proteins has been widely used for studying variation in fungal populations. El-Akkad (1997) found heterogeneity in protein banding patterns among the AG-4 isolates of $R$. solani. Hussein et al. (2000) used cluster analysis to compare protein banding patterns obtained by sodium dodecyl sulfate-polyacrylamide gel electrophoresis (SDS-PAGE) from 17 isolates of multinucleate $R$. solani (AG-4). A clear-cut relationship of protein profiles of the isolates with virulence, geographic origin, or source (cultivar used in isolation) was weak. These results suggested that AG-4 of $R$. solani is a heterogeneous group of isolates.

Mohammadi et al. (2003) studied the genetic variation among 20 isolates of $R$. solani AG-1 subgroups (AG-1-IA and AG-1-IB) collected from the Mâzandaran Province, Iran, and standard isolates of these subgroups by total soluble protein profile. The soluble protein patterns were similar between the $R$. solani isolates examined; however, minor differences in banding pattern were observed between the two subgroups. Based on cluster analysis and similarity matrix, the fungal isolates were divided into two distinct groups, I and II, consistent with the previously reported AG-1-IA and AG-1-IB subgroups in AG1 (Mohammadi et al., 2003). Random amplified polymorphic DNA (RAPD) markers allow the identification of species or isolates, and the construction of dendograms from the computed distances (Williams et al., 1990). Genetic variation in Australian isolates of $R$. solani was analyzed by RAPD. All of the anastomosis groups (including subgroups) tested could be distinguished. For some groups, there was considerable variation in the fingerprint patterns between isolates. This variation was more marked between isolates from different geographic locations. Other groups showed very little variation between isolates.

RAPD-PCR (polymerase chain reaction) analysis is a very useful alternative in anastomosis grouping for identification of isolates of $R$. solani (Duncan et al., 1993). Twelve isolates of $R$. solani 
and fifteen isolates of $R$. bataticola causing root rot of cotton were studied for their pathogenicity and genetic diversity using RAPD markers. The similarity values of RAPD profiles in $R$. solani isolates ranged from 0.35 to 1.00 with an average of 0.63 among all the isolates. Eighteen primers were used to fingerprint the individual isolates. Cluster analysis using unweighted pair-group method with arithmetic average (UPGMA) could distinguish $R$. solani and $R$. bataticola isolates into two separate fingerprint groups. Molecular markers are useful tools for detecting genetic variation in the population of $R$. solani (Monga et al., 2004). A method based on restriction analysis of PCR amplified ribosomal DNA was developed for the rapid characterization of large populations of $R$. solani at the anastomosis group (AG) level. The PCR-based procedure described in this paper provides a rapid method for AG typing of $R$. solani in relation to geographic locations in Egypt and variability of genetic contents.

The present investigation was initiated to determine whether $R$. solani isolates can be distinguished by their different locations in Egypt, pathogenicity to cotton, and the anastomosis grouping in conjunction with their protein and DNA patterns.

\section{MATERIAL AND METHODS}

\section{Isolate collection}

Twenty-one isolates of $R$. solani, originating from cotton seedlings, were obtained from the fungal collection of the Cotton Disease Research Section, Plant Pathology Research Institute, Agriculture Research Centre, Giza, Egypt.

\section{Pathogenicity test}

A substrate for the growth of isolates was prepared in $500-\mathrm{mL}$ glass bottles; each bottle contained $50 \mathrm{~g}$ sorghum grains and $40 \mathrm{~mL}$ tap water. The bottles were autoclaved for 30 min. Isolate inoculum, taken from 1-week-old culture on PDA, was aseptically introduced into the bottle and allowed to colonize the substrate for three weeks.

The test was carried out by using autoclaved clay loam soil. Batches of soil were infested separately with each isolate at the rate of $1 \mathrm{~g} / \mathrm{kg}$ soil. Infested soil was dispensed in 15$\mathrm{cm}$ diameter clay pots and these were planted with 10 seeds per pot of cultivar Giza 86 ( 5 replicates). In the control treatment, autoclaved sorghum was added to the autoclaved soil. Pots were randomly distributed on a greenhouse bench at a temperature of $24^{\circ} \pm 3^{\circ} \mathrm{C}$. Pre-emergence damping-off was recorded 15 days after planting, while post-emergence damping-off, survival of plant, height $(\mathrm{cm})$ and dry weight (mg/plant) were recorded 45 days after planting.

\section{Molecular studies}

Possible genetic variations among $R$. solani isolates were determined using by SDSPAGE protein fingerprinting and RAPD-PCR analysis.

\section{Extraction of proteins from $R$. solani isolates}

Proteins were prepared according to the methods described by Guseva and Gromova (1982). The mycelium grown for 8 days at $20^{\circ}-25^{\circ} \mathrm{C}$ in liquid Czapeck's medium was harvested 
by filtration through cheesecloth, washed with distilled water several times, and freeze-dried. This frozen mycelium was suspended in phosphate buffer, $\mathrm{pH} 8.3$ (1-3 mL/g mycelium), mixed thoroughly with glass beads and ground in liquid nitrogen to a fine powder. The ground mycelium was centrifuged at $19,000 \mathrm{rpm}$ for $30 \mathrm{~min}$ at $0^{\circ} \mathrm{C}$. The protein content in supernatant was estimated according to Bradford (1976) using bovine serum albumin as the protein standard.

\section{Electrophoresis of soluble protein (SDS-PAGE)}

Each supernatant was mixed with an equal volume of a solution consisting of (by volume) $64 \%$ buffer (0.15 M Tris-HCl, pH 6.8), 20\% glycerol; 6\% SDS; $10 \%$ 2-mercaptoethanol and $0.1 \%$ bromophenol blue, before boiling in a water bath for $3 \mathrm{~min}$. Twenty-microliter samples (40 $\mu \mathrm{g}$ protein) were subjected to electrophoresis on a $7.5 \%$ polyacrylamide gel prepared in $0.1 \%$ SDS with a $3.5 \%$ stacking gel (Laemmli, 1970). Electrophoresis was performed in a vertical slab gel $(16 \times 18 \times 0.15 \mathrm{~cm})$. Gels were stained with silver nitrate for the detection of protein bands (Sammons et al., 1981).

\section{Gel analysis for protein}

Protein patterns obtained by SDS-PAGE were clustered using a gel documentation system (Uvitec, Cambridge, UK) by UPGMA according to Sneath and Sokal (1973).

\section{Extraction of DNA from $R$. solani isolates}

$R$. solani cultures were grown in a $250-\mathrm{mL}$ Erlenmeyer flasks containing $50 \mathrm{~mL}$ potato dextrose broth at $23^{\circ} \mathrm{C}$ for 4 days. Cultures were filtered through microglass filters, and the mycelia were frozen in liquid nitrogen and ground to a fine powder in a mortar. DNA was extracted from $50 \mathrm{mg}$ fresh mat according to Guo et al. (2005).

\section{RAPD technique}

For each $R$. solani isolate tested, $30 \mathrm{ng}$ extracted DNA were used for the amplification reaction. The PCR mixture contained PCR beads (Amersham Pharmacia Biotech), which contained all the necessary reagents except the primer and DNA, which were added separately. Primer, nucleotide sequence and $\mathrm{G}+\mathrm{C}$ percentage of test primers used in these RAPD reactions are shown in Table 1. For each primer tested, $1.0 \mu \mathrm{L}$ was added to the mixture containing DNA extract. The total volume was adjusted to $25 \mu \mathrm{L}$ by adding sterile distilled water. The PCR amplification protocol (Thermocycler T1, Biometra, Germany) was carried out as follows:

\begin{tabular}{|c|c|c|}
\hline Primer No. & Sequence & $\mathrm{G}+\mathrm{C}(\%)$ \\
\hline 1 & 5'-GGTGCGGGAA-3' & 70 \\
\hline 2 & 5'-GTTTCGCTCC-3' & 60 \\
\hline 3 & 5'-GTAGACCCGT-3' & 60 \\
\hline 4 & 5'-AAGAGCCCGT-3' & 60 \\
\hline 5 & 5'-AACGCGCAAC-3' & 60 \\
\hline
\end{tabular}


a) denaturation at $95^{\circ} \mathrm{C}$ for 5 min (one cycle); b) 45 cycles, each consisting of denaturation at $95^{\circ} \mathrm{C}$ for $1 \mathrm{~min}$, annealing at $36^{\circ} \mathrm{C}$ for $1.0 \mathrm{~min}$, and extension at $72^{\circ} \mathrm{C}$ for $2 \mathrm{~min}$; c) a final extension at $72^{\circ} \mathrm{C}$ for $5 \mathrm{~min}$ (one cycle), and d) hold at $4^{\circ} \mathrm{C}$.

\section{DNA electrophoresis}

For all samples, $15 \mu \mathrm{L}$ amplified DNA was electrophoresed using a Bio-Rad Wide Mini-Sub Cell GT electrophoresis unit on $2 \%$ agarose gels containing $0.5 \mu \mathrm{g} / \mathrm{mL}$ ethidium bromide, at constant $75 \mathrm{~V}$ and $60 \mathrm{~mA}$, and visualized with a UV trans-illuminator.

\section{Gel analysis for DNA}

The DNA gel was scanned for band Rf using a gel documentation system (AAB Advanced American Biotechnology, Fullerton, CA, USA). The different molecular weights of bands were determined against a DNA standard (kb DNA ladder, Stratagene, Canada) with molecular weights of 250, 500, 750, 1000, 1500, 2000, 3000, 4000, 5000, 6000, 7000, 8000, $9000,10,000$, and $12,000 \mathrm{bp}$. The similarity level was determined by UPGMA.

\section{Statistical analysis of pathogenicity test}

The pathogenicity test was carried out using a randomized complete block design with five replicates. The percentage data were transformed into $\sqrt{\mathrm{x}+0.5}$ or arcsine values to obtain approximately constant variance before carrying out analysis of variance (ANOVA). The Duncan multiple range test was used to compare isolate means. ANOVA was carried out using the MSTAT-C statistical package.

\section{RESULTS}

\section{Anastomosis typing of Rhizoctonia spp isolates}

Table 2 shows the $R$. solani isolates used in this investigation, originating from 8 governorates of lower Egypt, where they were categorized into 3 anastomosis groups, namely AG-2-2, AG-4-HG-I and AG-5. It is obvious that different AGs were found in the same governorate, except the two isolates from Gharbiya, which belonged to AG-4-HG-I, and one from Qualubiya, which belonged to AG-2-2.

\section{Pathogenicity test}

The pathogenicity test of $21 R$. solani isolates was evaluated on cotton cultivar Giza 86 under greenhouse conditions (Table 3). Eleven isolates significantly increased pre-emergence damping-off, 14 isolates decreased survival significantly. Plant height and dry weight were significantly affected by 6 and 5 isolates, respectively. Isolates Nos. 28, 32, 39, 43, 26, 33,41 , and 45 were the most pathogenic because they significantly affected all parameters except post-emergence damping-off and dry weight for isolate 45 . None of the isolates tested caused significant post-emergence damping-off infection, while $52.38 \%$ of the isolates caused 
significant pre-emergence damping-off (Table 4). The most pathogenic isolates were those isolated from Beheira, Sharqiya, Minufiya, Gharbiya, and Damietta governorates, representing $21.43 \%$ of the total pathogenic isolates (Table 5).

Table 2. Anastomosis groups, governorates and region of Rhizoctonia solani used in pathogenicity test.

\begin{tabular}{lcll}
\hline Isolate No. & Anastomosis group (AG) & Governorate & Region \\
\hline 26 & $4-$ HG-I & Daquahlyia & East Delta \\
27 & 5 & Daquahlyia & East Delta \\
28 & $2-2$ & Minufiya & Mid-Delta \\
29 & $4-$ HG-I & Minufiya & Mid-Delta \\
30 & $4-$ HG-I & Minufiya & Mid-Delta \\
31 & $2-2$ & Minufiya & Mid-Delta \\
32 & $2-2$ & Sharqiya & East Delta \\
33 & $2-2$ & Sharqiya & East Delta \\
34 & $4-$ HG-I & Sharqiya & East Delta \\
35 & 5 & Sharqiya & East Delta \\
36 & 5 & Kafr El-Sheikh & North Delta \\
37 & $4-H G-I$ & Kafr El-Sheikh & North Delta \\
39 & $2-2$ & Beheira & West Delta \\
40 & $2-2$ & Beheira & West Delta \\
41 & 5 & Beheira & West Delta \\
42 & $4-H G-I$ & Gharbiya & Mid-Delta \\
43 & $4-H G-I$ & Gharbiya & Mid-Delta \\
45 & $2-2$ & Damietta & East Delta \\
46 & $2-2$ & Damietta & East Delta \\
47 & $4-H G-I$ & Damietta & East Delta \\
50 & $2-2$ & Qualubiya & South Delta \\
\hline
\end{tabular}

Table 3. Pathogenicity of Rhizoctonia solani isolates on cotton seedlings (cultivar Giza 86) under greenhouse conditions.

\begin{tabular}{|c|c|c|c|c|c|}
\hline Isolate No. & $\begin{array}{c}\text { Pre-emergence } \\
\text { damping-off }(\%)^{\mathrm{a}}\end{array}$ & $\begin{array}{l}\text { Post-emergence } \\
\text { damping-off }(\%)^{\mathrm{b}}\end{array}$ & Survival $(\%)^{\mathrm{a}}$ & Plant height $(\mathrm{cm})$ & $\begin{array}{c}\text { Dry weight } \\
\text { (mg/plant) }\end{array}$ \\
\hline 26 & $58^{\mathrm{c}-\mathrm{f}^{*}}$ & $2^{\mathrm{ab}}$ & $40^{\mathrm{f}-\mathrm{k}^{*}}$ & $15.50^{\mathrm{a}-\mathrm{d}}$ & $293^{\mathrm{f}-\mathrm{i}}$ \\
\hline 27 & $22^{e-j}$ & $2^{\mathrm{b}}$ & $76^{\mathrm{a}-\mathrm{f}}$ & $17.67^{\mathrm{a}-\mathrm{c}}$ & $506^{a-f}$ \\
\hline 28 & $88^{\mathrm{a}^{*}}$ & $4^{b}$ & $8^{\mathrm{m}^{*}}$ & $3.00^{\mathrm{g}^{*}}$ & $106^{\mathrm{ij*}}$ \\
\hline 29 & $16^{\mathrm{j}}$ & $0^{\mathrm{ab}}$ & $84^{\mathrm{ab}}$ & $19.13^{\mathrm{a}-\mathrm{c}}$ & $435^{b-f}$ \\
\hline 30 & $22^{\mathrm{g}-\mathrm{j}}$ & $2^{\mathrm{b}}$ & $76^{\mathrm{a}-\mathrm{d}}$ & $18.73^{\mathrm{a}-\mathrm{c}}$ & $431^{\mathrm{b}-\mathrm{f}}$ \\
\hline 31 & $44^{\mathrm{c}-\mathrm{i}}$ & $4^{\mathrm{b}}$ & $52^{\mathrm{c}-\mathrm{k}^{*}}$ & $15.07^{\mathrm{b}-\mathrm{d}}$ & $337^{\mathrm{d}-\mathrm{h}}$ \\
\hline 32 & $100^{\mathrm{a}^{*}}$ & $0^{\mathrm{b}}$ & $0^{\mathrm{m}^{*}}$ & $0.00^{\mathrm{g}^{*}}$ & $0^{j^{*}}$ \\
\hline 33 & $68^{\mathrm{bc} *}$ & $2^{\mathrm{b}}$ & $30^{i-k^{*}}$ & $16.57^{\mathrm{a}-\mathrm{d}}$ & $494^{\mathrm{a}-\mathrm{f}}$ \\
\hline 34 & $58^{\mathrm{c}-\mathrm{f}^{*}}$ & $4^{\mathrm{ab}}$ & $38^{\mathrm{g}-\mathrm{k}^{*}}$ & $15.33^{\mathrm{a}-\mathrm{d}}$ & $306^{\mathrm{e}-\mathrm{h}}$ \\
\hline 35 & $42^{c-j}$ & $2^{\mathrm{b}}$ & $56^{\mathrm{b}-\mathrm{k}}$ & $19.40^{\mathrm{a}-\mathrm{c}}$ & $571^{\mathrm{a}-\mathrm{c}}$ \\
\hline 36 & $48^{\mathrm{c}-\mathrm{i}}$ & $4^{\mathrm{ab}}$ & $48^{\mathrm{c}-\mathrm{k}^{*}}$ & $17.90^{\mathrm{a}-\mathrm{c}}$ & $690^{\mathrm{a}^{*}}$ \\
\hline 37 & $60^{b-d^{*}}$ & $6^{\mathrm{ab}}$ & $34^{\mathrm{ik*}}$ & $13.63^{\mathrm{cd}}$ & $371^{\mathrm{b}-\mathrm{h}}$ \\
\hline 39 & $90^{\mathrm{a}^{*}}$ & $0^{\mathrm{b}}$ & $10^{\mathrm{m}^{*}}$ & $2.33^{\mathrm{g}^{*}}$ & $67^{j^{*}}$ \\
\hline 40 & $56^{\mathrm{ce-*}}$ & $4^{\mathrm{ab}}$ & $40^{\mathrm{h}-\mathrm{k}^{*}}$ & $11.47^{\mathrm{de}}$ & $353^{\mathrm{c}-\mathrm{h}}$ \\
\hline 41 & $60^{\mathrm{bc} *}$ & $6^{\mathrm{ab}}$ & $34^{\mathrm{k} 1^{*}}$ & $8.50^{\mathrm{ef} *}$ & $195^{\mathrm{g}-\mathrm{j}}$ \\
\hline 42 & $20^{\mathrm{g}-\mathrm{j}}$ & $10^{\mathrm{ab}}$ & $70^{\mathrm{a}-\mathrm{h}}$ & $15.47^{\mathrm{a}-\mathrm{d}}$ & $487^{\mathrm{a}-\mathrm{f}}$ \\
\hline 43 & $88^{a^{*}}$ & $4^{\mathrm{ab}}$ & $8^{\operatorname{lm} *}$ & $3.73^{\mathrm{fg} *}$ & $72^{\mathrm{j}^{*}}$ \\
\hline 45 & $88^{\mathrm{Ab}^{*}}$ & $2^{\mathrm{b}}$ & $10^{\operatorname{lm} *}$ & $5.17^{\mathrm{fg}^{*}}$ & $168^{\mathrm{h}-\mathrm{j}}$ \\
\hline 46 & $32^{\mathrm{c}-\mathrm{j}}$ & $2^{\mathrm{b}}$ & $66^{a-j}$ & $17.73^{\mathrm{a}-\mathrm{c}}$ & $498^{\mathrm{a}-\mathrm{f}}$ \\
\hline 47 & $22^{e-j}$ & $0^{\mathrm{b}}$ & $78^{\mathrm{a}-\mathrm{e}}$ & $17.73^{\mathrm{a}-\mathrm{c}}$ & $573^{\mathrm{a}-\mathrm{c}}$ \\
\hline 50 & $40^{\mathrm{c}-\mathrm{j}}$ & $6^{\mathrm{ab}}$ & $54^{\mathrm{c}-\mathrm{k}^{*}}$ & $13.67^{\mathrm{cd}}$ & $326^{\mathrm{d}-\mathrm{h}}$ \\
\hline Control & $14^{\mathrm{ij}}$ & $0^{\mathrm{b}}$ & $86^{a-b}$ & $16.47^{\mathrm{a}-\mathrm{d}}$ & $507^{\mathrm{a}-\mathrm{f}}$ \\
\hline
\end{tabular}

a Percentage data were transformed into arcsine angles before carrying out the analysis of variance to produce approximately constant variance. ${ }^{b}$ Percentage data were transformed into $\sqrt{x+0.5}$ angles before carrying out the analysis of variance to produce approximately constant variance. ${ }^{c}$ Means in a column followed by the same superscript letter(s) are not significantly different according to the Duncan multiple range test $(\mathrm{P}=0.05)$; asterisks denote a significant difference from the control. 
Table 4. Distribution of Rhizoctonia solani isolates based on their effects on cotton seedlings (cultivar Giza 86).

\begin{tabular}{lccccc}
\hline Total No. of isolates tested & \multicolumn{4}{c}{ Percentage of isolates, which are significantly affected } \\
\cline { 2 - 6 } & $\begin{array}{c}\text { Pre-emergence } \\
\text { damping-off }(\%)\end{array}$ & $\begin{array}{c}\text { Post-mergence } \\
\text { damping-off }(\%)\end{array}$ & Survival (\%) & Plant height (cm) & $\begin{array}{c}\text { Dry weight } \\
(\mathrm{mg} / \text { plant })\end{array}$ \\
\hline 21 & 52.38 & 0.00 & 66.67 & 28.57 & 23.81 \\
\hline
\end{tabular}

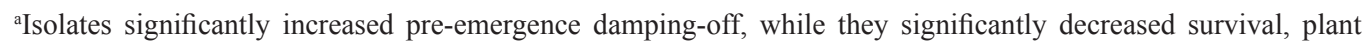
height and dry weight.

Table 5. Distribution of Rhizoctonia solani isolates based on geographic origin.

\begin{tabular}{|c|c|c|c|c|c|}
\hline \multirow[t]{2}{*}{ Geographic origin } & \multirow[t]{2}{*}{ Total No. of isolates tested } & \multirow[t]{2}{*}{ No. of pathogenic isolates } & \multicolumn{3}{|c|}{ Pathogenic isolates as percentage of } \\
\hline & & & Governorate & Total isolates & Pathogenic isolates \\
\hline Beheira & 3 & 3 & 100.00 & 14.29 & 21.43 \\
\hline Minufiya & 4 & 2 & 50.00 & 9.52 & 14.29 \\
\hline Daquahlyia & 2 & 1 & 50.00 & 4.76 & 7.14 \\
\hline Qualubiya & 1 & 1 & 100.00 & 4.76 & 7.14 \\
\hline Gharbiya & 2 & 1 & 50.00 & 4.76 & 7.14 \\
\hline Sharqiya & 4 & 3 & 75.00 & 14.29 & 21.43 \\
\hline Kafr El-Sheikh & 2 & 2 & 100.00 & 9.52 & 14.29 \\
\hline Damietta & 3 & 1 & 33.33 & 4.76 & 7.14 \\
\hline
\end{tabular}

\section{Differentiation among $R$. solani isolates based on their protein banding patterns obtained by SDS-PAGE}

Considering data generated from SDS-PAGE (Figure 1) and phenogram (Figure 2), it is apparent that isolates separated into a large number of clusters. The first cluster included 4 isolates $(34,35,33$, and 30$)$ with an overall similarity level (SL) of $34 \%$. For the anastomosis groups, isolates 34 and 30, belonging to AG-4-HG-I, showed SL of 64\%. For geographic regions, isolates 34, 35 and 33 from the East Delta region showed an SL of 48\%.

M $2627282930313233343536373940 \quad 43454142 \quad 46 \quad 47 \quad 50$

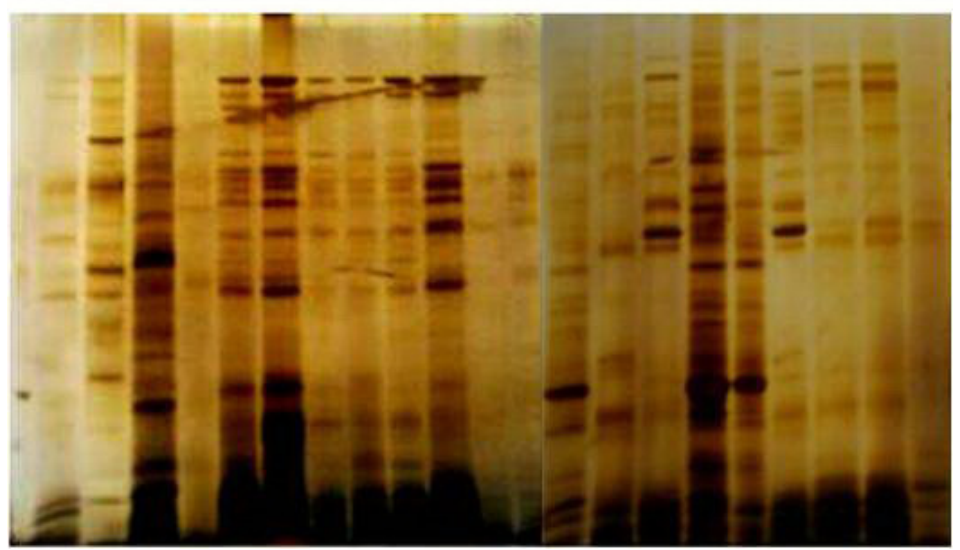

Figure 1. Protein patterns obtained by SDS-PAGE from 21 isolates of Rhizoctonia solani. Lane M= molecular weight. 


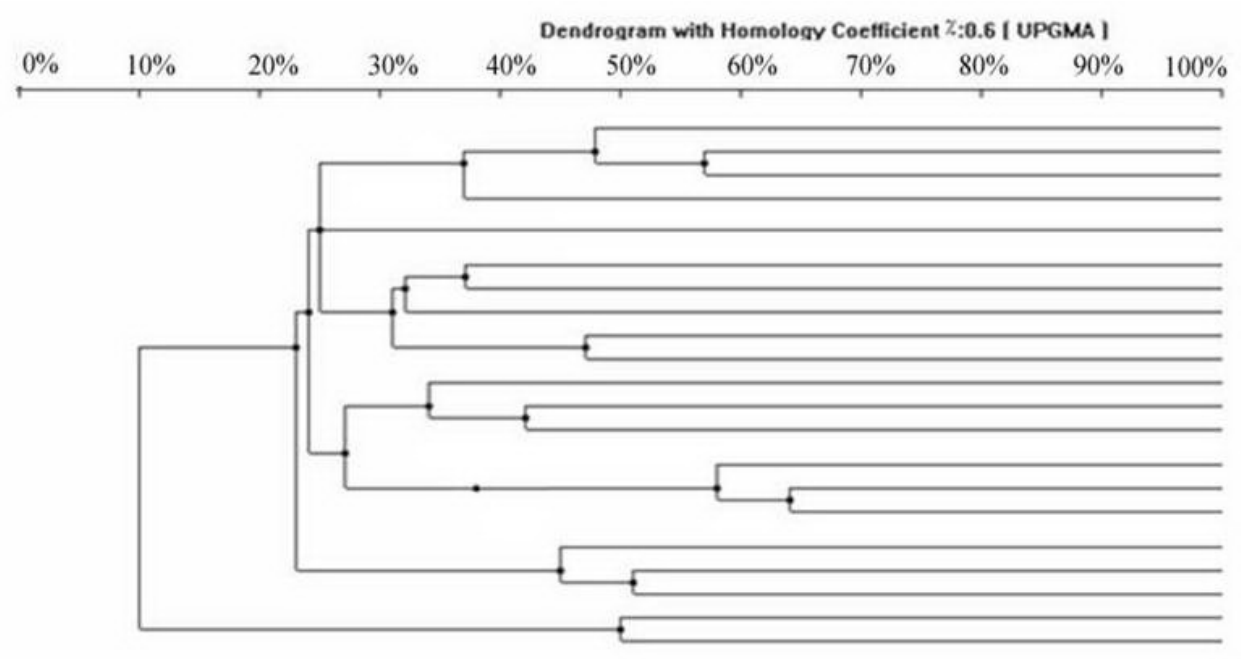

Isolates

Figure 2. Dendrogram of electrophoretic protein patterns obtained by SDS-PAGE from 21 isolates of Rhizoctonia solani.

The second cluster included 1 isolate (36). The third cluster included 5 isolates (37, 43, 27, 29, and 31) with an SL of 31\%. For the anastomosis groups, isolates 37 and 43, belonging to AG-4-HG-I, showed an SL of 38\%. For geographic regions, isolates 29 and 31 from the Mid-Delta region showed an SL of $47 \%$.

The fourth cluster included 3 isolates (28, 50 and 31) with an SL of $32 \%$. The fifth cluster included 3 isolates (40, 41 and 42) with an SL of 57\%.

The sixth cluster included 3 isolates (32, 45 and 46) with an SL of $45 \%$. All of these isolates from the East Delta region showed an SL of $45 \%$. The seventh cluster included 2 isolates (26 and 39) with an SL of 50\%. All the isolates were the most pathogenic because they significantly affected all parameters.

\section{Genetic characterization of $R$. solani isolates}

Genetic variations were evaluated by PCR amplification using a set of 5 random 10mer primers. The amplification products were analyzed for polymorphisms by gel electrophoresis to determine whether pathotypes could be distinguished at the molecular level.

\section{RAPD profiles of $R$. solani isolates obtained using the 5 primers}

\section{$R A P D$ profile of $21 R$. solani isolates obtained with primer 1}

Dendrogram analysis grouped the isolates into two main clusters at a genetic similarity level (GSL) of $93.96 \%$ based on the banding pattern (Figure 3). GSL between the isolates tested ranged from 75.23 to $99.49 \%$ (Figure 3 ). The first cluster consisted of many subclusters, where the main subcluster included 15 isolates $(26,28,27,33,35,41,30,47,31,50,43,32$, 40, 36, and 39). 


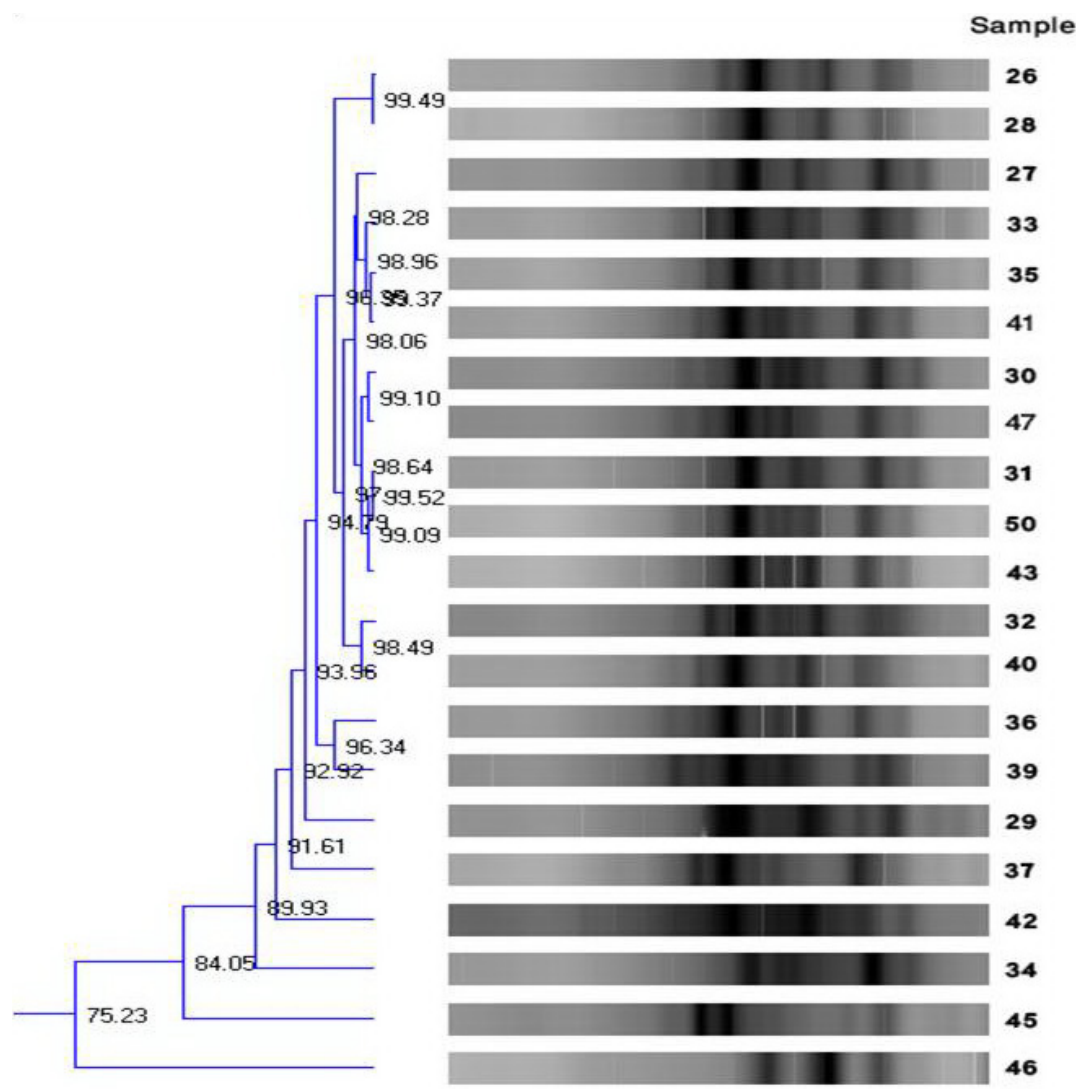

Figure 3. Dendrogram showing the genetic relationships among 21 Rhizoctonia solani isolates based on RAPD analysis, using primer 1.

For geographic regions, isolates 26, 27, 33, 35, 47, 31, and 32 from the East Delta overlapped with isolates 28, 30, 31, and 43 from the Mid-Delta and other isolates from other regions.

For the anastomosis groups, isolates 30 and 47, belonging to AG-4-HG-I, showed a high GSL of $99.10 \%$. Isolates Nos. 27, 35 and 41, belonging to AG-5, showed a high GSL of 98.28\%. Isolates 31 and 50, belonging to AG-5 showed a high GSL of $99.52 \%$, and isolates 32 and 40, belonging to AG-2-2, showed a high GSL of $98.49 \%$.

For the pathogenicity test, isolates $26,28,32,33,39,41,43$, and 45 were the most pathogenic because they significantly affected all stages of plant infection (pre- and postemergence damping-off and survival) and plant height and dry weight. These isolates showed a GSL of $89.05 \%$. Isolates 26 and 28 showed a high GSL of $99.49 \%$, and isolates 33 and 41 showed a high GSL of $96.35 \%$.

\section{RAPD profile of $21 \boldsymbol{R}$. solani isolates obtained with primer 2}

Dendrogram analysis grouped the isolates into two main clusters with a GSL of $80.80 \%$ based on the banding pattern (Figure 4 ). 


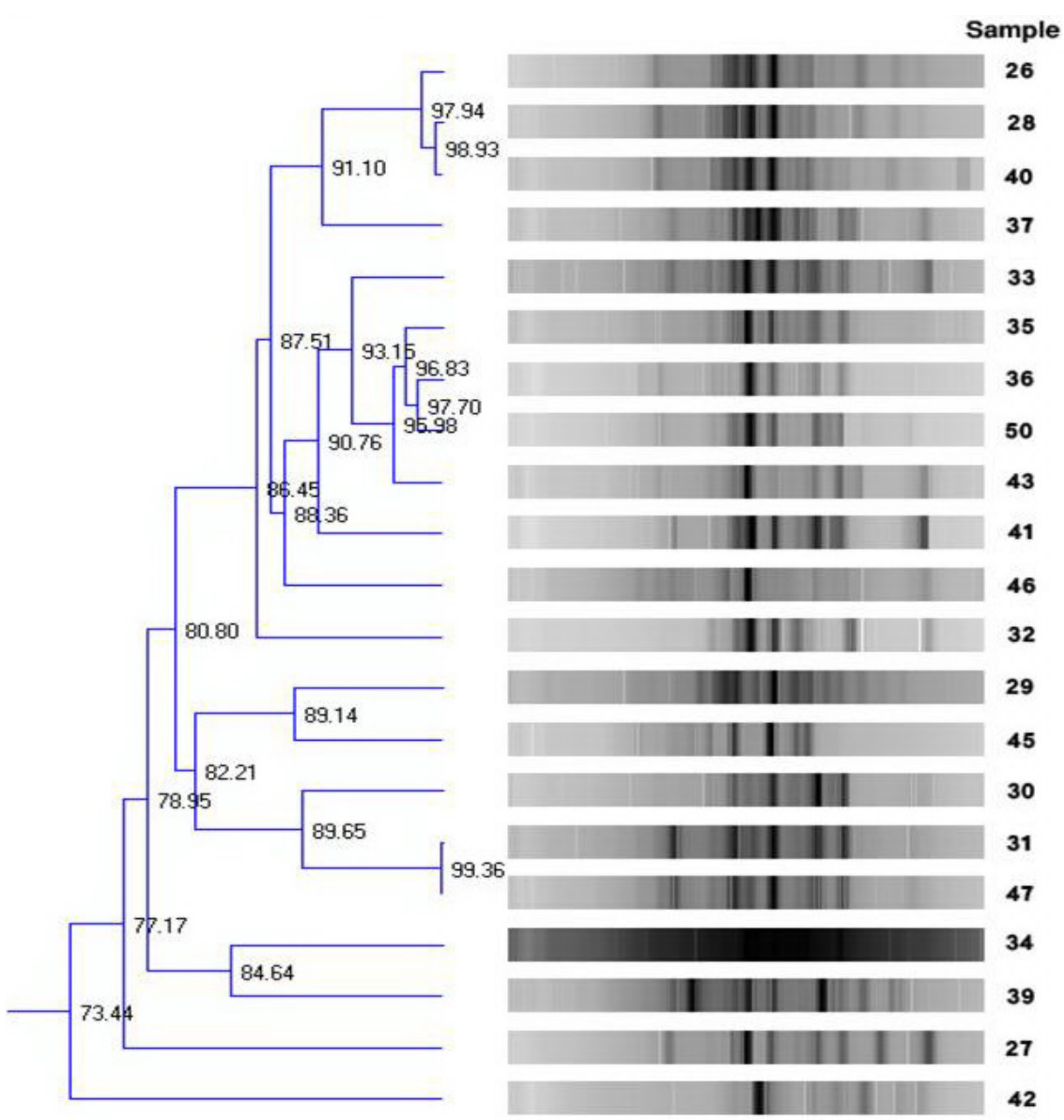

Figure 4. Dendrogram showing the genetic relationships among 21 Rhizoctonia solani isolates based on RAPD analysis, using primer 2 .

The GSL between the isolates tested ranged from 74.44 to $99.36 \%$ (Figure 4 ). The first cluster consisted of many subclusters, including seventeen isolates $(26,28,40,37,33,35,36$, $50,43,41,46,32,29,45,30,31$, and 47).

For geographic regions, isolates 26, 33, 35, 32, 45, and 47 from the East Delta overlapped with isolates 28, 30, 31, 43, and 29 from the Mid-Delta and other isolates from other regions.

For the anastomosis groups, isolates 26 and 37, belonging to AG-4-HG-I, showed a GSL of $91.10 \%$. Isolates 29,30 and 47, belonging to AG-4-HG-I, showed a GSL of $82.21 \%$. Isolates 35 and 36, belonging to AG-5, showed a high GSL of $97.70 \%$. Isolates 31 and 50 , belonging to AG-2-2, showed high GSL of $99.52 \%$, and isolates 32 and 40 , belonging to AG2-2, showed a high GSL of $98.49 \%$.

The pathogenicity test indicated that the isolates $26,28,32,33,39,41,43$, and 45 were the most pathogenic. Isolates 26 and 28 showed a high GSL of $97.94 \%$. Isolates 33 and 43 showed a high GSL of $95.98 \%$, and isolates 33,43 and 41 showed a GSL of $93.15 \%$. 


\section{RAPD profile of $21 R$. solani isolates obtained with primer 3}

Dendrogram analysis grouped the isolates into two main clusters with a GSL of $89.40 \%$ based on the banding pattern (Figure 5). The GSL between the isolates tested ranged from 71.24 to $99.26 \%$ (Figure 5). The first cluster consisted of many subclusters, including 17 isolates $(26,28,27,31,33,34,37,43,41,46,47,50,36,39,42,40$, and 45).

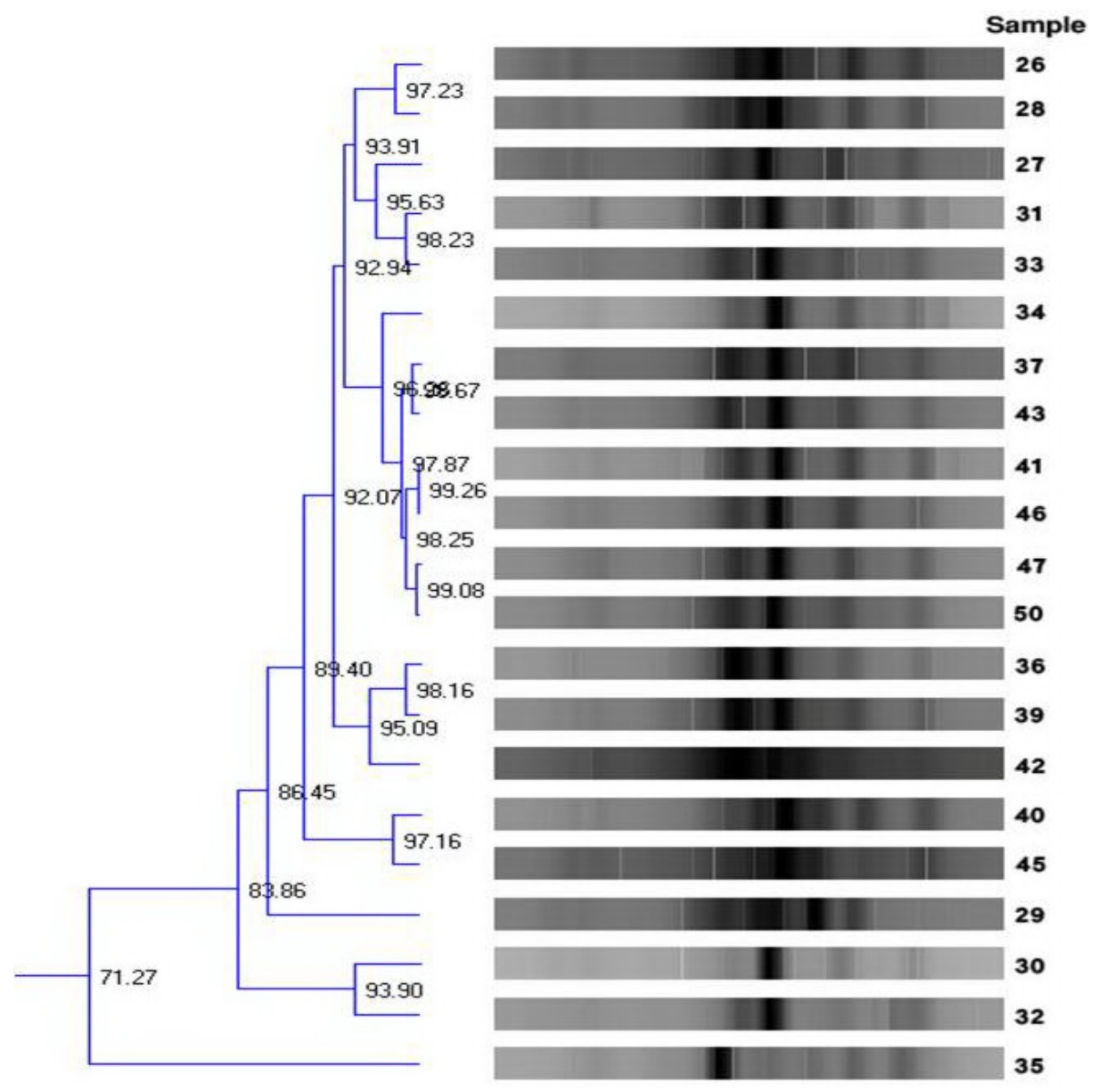

Figure 5. Dendrogram showing the genetic relationships among 21 Rhizoctonia solani isolates based on RAPD analysis, using primer 3 .

For geographic regions, isolates 26, 27, 33, 34, 45, 46, and 47 from the East Delta overlapped with isolates 28, 31, 43, and 42 from the Mid-Delta and other isolates from other regions.

For the anastomosis groups, isolates 37 and 43, belonging to AG-4-HG-I, showed a GSL of $98.67 \%$, and isolates 34,37 and 43, also belonging to AG-4-HG-I, showed a high GSL of $97.87 \%$. Isolates 31 and 33, belonging to AG-2-2, showed a high GSL of $98.23 \%$. Isolates 
40 and 45, belonging to AG-2-2, showed a high GSL of 97.16\%, and isolates 46 and 50, belonging to AG-2-2 showed a high GSL of $98.25 \%$.

The pathogenicity test showed that isolates $26,28,32,33,39,41,43$, and 45 were the most pathogenic. Isolates 26 and 28 showed a high GSL of $97.23 \%$, and isolates 43 and 41 showed a high GSL of $98.25 \%$.

\section{RAPD profile of $21 R$. solani isolates obtained with primer 4}

Dendrogram analysis grouped the isolates into two main clusters with a GSL of $82.72 \%$ based on the banding pattern (Figure 6). GSL between the isolates tested ranged from 65.19 to $99.19 \%$ (Figure 6). The first cluster consisted of many subclusters, including 20 isolates $(26,28,40,29,45,34,42,37,39,27,36,41,31,33,43,35,50,30,47$ and 46).

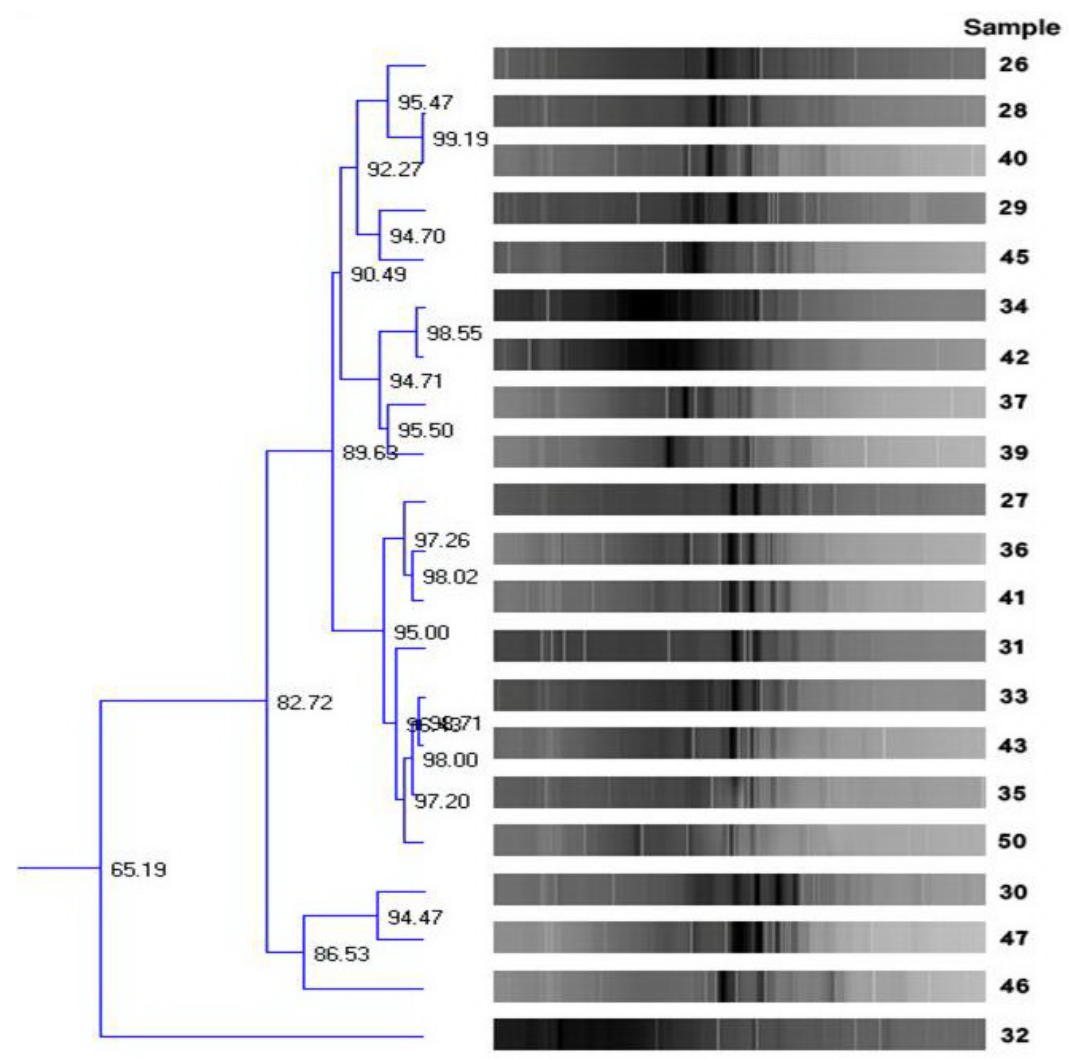

Figure 6. Dendrogram showing the genetic relationships among 21 Rhizoctonia solani isolates based on RAPD analysis, using primer 4.

For geographic regions, the first cluster included isolates $26,27,33,34,35$, and 45 from the East Delta, overlapping with isolates 28, 29, 31, 42, and 43 from the Mid-Delta and other isolates from other regions. 
For the anastomosis groups, the first cluster included isolates 26 and 29, belonging to AG-4-HG-I, which showed a GSL of $92.27 \%$, and isolates 34 and 42, also belonging to AG4-HG-I, which showed a high GSL of $98.55 \%$. Isolates 34, 42 and 37, belonging to the same anastomosis group, showed a high GSL of $94.71 \%$. Isolates 27,36 and 41 , belonging to AG-5, showed a high GSL of $97.26 \%$. Isolates 28 and 42, belonging to AG-2-2, showed a high GSL of $99.19 \%$, and isolates 31,33 and 50, belonging to the same anastomosis group, showed a high GSL of $96.13 \%$.

The pathogenicity test revealed that isolates $26,28,32,33,39,41,43$, and 45 were the most pathogenic. Isolates 26 and 28 showed a high GSL of $95.47 \%$, and isolates 33 and 43 showed a high GSL of $98.71 \%$.

\section{RAPD profile of $21 \boldsymbol{R}$. solani isolates obtained with primer 5}

Dendrogram analysis grouped the isolates into two main clusters with a GSL of $80.93 \%$ based on the banding pattern (Figure 7). GSL between the isolates tested ranged from 75.38 to $99.00 \%$ (Figure 7). The main subcluster included 17 isolates $(27,39,36,37,40,29$, $30,32,33,43,50,47,41,42,31,34$, and 35$)$.

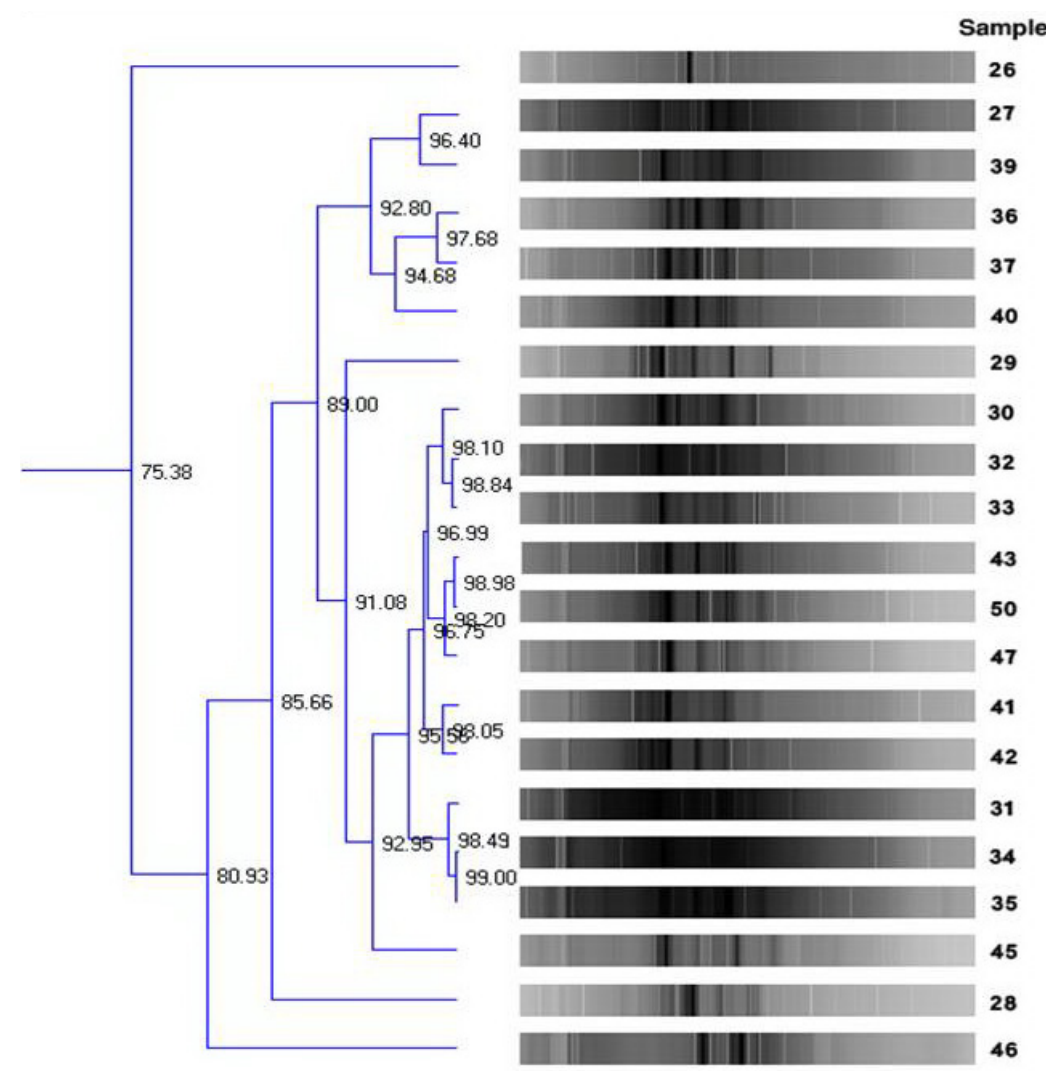

Figure 7. Dendrogram showing the genetic relationships among 21 Rhizoctonia solani isolates based on RAPD analysis, using primer 5 
For geographic regions, the main subcluster included isolates 7, 32, 33, 47, 34, and 35 from the East Delta overlapping with isolates 29, 30, 31, 42, and 43 from the Mid-Delta and other isolates from other regions.

For the anastomosis groups, the main subcluster included isolates 43 and 47, belonging to AG-4-HG-I, which showed a high GSL of $98.20 \%$. Isolates 32 and 33, belonging to AG-2-2, showed a high GSL of $98.84 \%$. Isolates 27 and 36, belonging to AG-5, showed a GSL of $92.80 \%$.

The pathogenicity test indicated that isolates $26,28,32,33,39,41,43$, and 45 were the most pathogenic. Isolates 32 and 33 showed a high GSL of $98.84 \%$, and isolates 33 and 43 showed a high GSL of $98.71 \%$.

\section{DISCUSSION}

It is obvious that different isolates behaved differently with respect to disease-causing ability in the pre-emergence stage, and that some isolates affected plant height as well as dry weight. Similar results were reported by Monga and Sheo-Raj (1994), Aqil and Batson (1999) and Asran (2001). The above-mentioned isolates resulted in a level of pre-emergence damping-off amounting to $88 \%$ or more. These isolates, except No. 43 belonged to AG-2-2. Considering the rest of the data, Table 3 reveals that there was no general trend correlating AGs with virulence. SDS-PAGE is a widely used technique in biochemistry, forensics, genetics, and molecular biology to separate proteins according to their electrophoretic mobility. SDS gel electrophoresis of samples allows the separation of molecules with identical charge per unit mass due to binding of SDS, resulting in fractionation by size. Protein profiling failed to correlate with the different parameters tested or estimated.

The results showed that protein profiling failed to correlate with the different parameters tested or estimated. Therefore, grouping isolates of $R$. solani based on their protein pattern obtained by SDS-PAGE is not related to their virulence, AGs or geographic origin, confirming previous results reported by El-Akkad (1997) for R. solani and Abdel-Sattar et al. (2008) for Macrophomina phaseolina isolated from cotton.

Molecular techniques, such as RAPD-PCR, use a small sample of the subject's DNA, which is then selectively amplified a million times, thus producing a large amount of concentrated DNAs (PCR products). PCR products can be separated into bands of different molecular weight DNAs by agarose gel electrophoresis. Banding patterns from an individual or population can then be used as a "fingerprint" that may distinguish it from other genetic types (Ruiz et al., 2000).

RAPD-PCR uses low specificity primers that are aligned at random with sequences in the genome. The standardized RAPD-PCR yields reproducible amplification patterns that are characteristic of the strains. RAPD-PCR yields different information, since it analyzes different sequences and detects different types of variations in DNA. RAPD-PCR detects differences along the entire genome, not only in particular sequences. Thus, this system is helpful in characterizing fungal isolates over long periods (Ortiz-Herrera et al., 2004).

Genetic variability among 21 isolates and geographic locations of $R$. solani was determined, using the RAPD technique. The banding patterns generated from these isolates by five primers showed high levels of genetic similarity between the isolates from the same AG or level of virulence or geographic origin.

The results showed that the genetic similarity between $R$. solani isolates obtained from the same geographic location indicated that there was a partial relationship between 
RAPD dendrogram and anastomosis grouping or level of virulence or geographic origin. The results demonstrate that RAPD technique is a useful marker system in determining the genetic characterization of isolates of $R$. solani.

\section{ACKNOWLEDGMENTS}

The authors extend their appreciation to the Deanship of the Scientific Research at King Saud University for funding the study through the research group project \#RGP-VPP-183.

\section{REFERENCES}

Abdel-Sattar MA, Aly AA and Omar MR (2008). Use of pathogenicity and protein electrophoresis to distinguish isolates of Macrophomina phaseolina pathogenic on cotton. J. Agric. Sci. Mansoura Univ. 33: 207-217.

Adams GC (1988). Thanatephorus cucumeris (Rhizoctonia solani), a species complex of wide host range. Adv. Plant Pathol. 6: 535-552.

Aqil T and Batson EW (1999). Evaluation of radical assay for screening cotton genotypes for resistance to the pathogens of seedling disease complex. Pak. J. Phyto. 11: 11-16.

Asran AA (2001). Studies on Cotton Rhizosphere Microorganisms and Their Role as Bio-Control Agents for Root Rot Diseases. PhD thesis, Cairo University, Cairo.

Bradford MM (1976). A rapid and sensitive method for the quantitation of microgram quantities of protein utilizing the principle of protein-dye binding. Anal. Biochem. 72: 248-254.

Carling DE, Baird RE, Gitaitis RD, Brainard KA, et al. (2002). Characterization of AG-13, a Newly Reported Anastomosis Group of Rhizoctonia solani. Phytopathology 92: 893-899.

Duncan S, Barton JE and O'Brien PA (1993). Analysis of variation in isolates of Rhizoctonia solani by random amplified polymorphic DNA assay. Mycol. Res. 97: 1075-1082.

El-Akkad SAF (1997). Studies on anastomosis groups of Rhizoctonia solani. PhD thesis, Cairo University, Cairo.

El-Samawaty AMA, Asran AA, Omar MR and Abd-Elsalam KA (2008). Anastomosis groups, pathogenicity, and cellulase production of Rhizoctonia solani from cotton. Pest Technol. 1: 117-124.

Fulton ND, Awaddle B and Thomas JA (1956). Influence of planting date on fungi isolated from diseased cotton seedlings. Plant Dis. Rep. 40: 556-558.

Guo JR, Schnieder F, Abd-Elsalam KA and Verreet JA (2005). Rapid and efficient extraction of genomic DNA from different phytopathogenic fungi using DNAzol reagent. Biotechnol. Lett. 27: 3-6.

Guseva NN and Gromova BB (1982). Chemical and Biochemical Methods for Studying Plant Immunity. All Union Institute of Plant Protection, Leningrad.

Hussein EM, Allam AD, Aly AA, Amein AM, et al. (2000). Separation by protein electrophoresis of Rhizoctonia spp. isolated from cotton seedlings. J. Agric. Sci. Mansoura Univ. 25: 4035-4046.

Laemmli UK (1970). Cleavage of structural proteins during the assembly of the head of bacteriophage T4. Nature 227: 680-685.

Mohammadi M, Banihashemi M, Hedjaroude GA and Rahimian H (2003). Genetic diversity among Iranian isolates of Rhizoctonia solani Kühn anastomosis group1 subgroups based on isozyme analysis and total soluble protein pattern. J. Phyto. 151: 162-170.

Monga D and Sheo-Raj (1994). Cultural and pathogenic variations in the isolates of Rhizoctonia species causing root rot of cotton. Indian Phytopathol. 47: 403-407.

Monga D, Ratore SS and Mayee CD (2004). Differentation of isolates of cotton root rot pathogens Rhizoctonia solani and R. bataticola using cultural characteristics, pathogenicity and RAPD markers. J. Plant Biochem. Biotechnol. 13: 135-139.

Ogoshi A (1972). Grouping of Rhizoctonia solani Kühn with hyphal anastomosis. Ann. Phytopathol. Soc. Japan 38: 117-122.

Ortiz-Herrera M, Geronimo-Gallegos A, Cuevas-Schacht F, Perez-Fernandez L, et al. (2004). RAPD-PCR characterization of Pseudomonas aeruginosa strains obtained from cystic fibrosis patients. Salud. Publica Mex. 46: 149-157.

Ruiz RA, Vacek DC, Parker PE and Wendel LE (2000). Using Randomly Amplified Polymorphic DNA Polymerase Chain Reaction (RAPD-PCR) to Match Natural Enemies to Their Host Plant. Proceedings of the X International Symposium on Biological Control of Weeds 4-14 July 1999 (Spencer NR, ed.). Montana State University, Bozeman, 289-293.

Rush CM, Carling ED, Harveson RM and Mathieson JT (1994). Prevalence and pathogenicity of anastomosis groups of 
Rhizoctonia solani from wheat and sugar beet in Texas. Plant Dis. 78: 349-352.

Sammons DW, Adams LD and Nishizawa EE (1981). Ultrasensitive silver-based colour staining of polypeptides in polyacrylamide gels. Electrophoresis 2: 135-141.

Sneath PHA and Sokal RR (1973). Numerical Taxonomy. Freeman, San Francisco.

Sneh B, Jabaji-Hare S, Neate S and Dijst G (1996). Rhizoctonia Species: Taxonomy, Molecular Biology, Ecology, Pathology and Disease Control. Kluwer Academic Publishers, Dordrecht.

Williams JG, Kubelik AR, Livak KJ, Rafalski JA, et al. (1990). DNA polymorphisms amplified by arbitrary primers are useful as genetic markers. Nucleic Acids Res. 18: 6531-6535. 